\title{
Environmental monitoring of surface ozone and other trace gases over different time scales: chemistry, transport and modeling
}

\author{
R. Venkanna $\cdot$ G. N. Nikhil $\cdot$ T. Siva Rao • \\ P. R. Sinha $\cdot$ Y. V. Swamy
}

Received: 23 July 2012/Revised: 3 December 2013/ Accepted: 5 March 2014/Published online: 9 April 2014

(C) Islamic Azad University (IAU) 2014

\begin{abstract}
Increasing concentration of tropospheric ozone $\left(\mathrm{O}_{3}\right)$ is a serious air pollution problem faced commonly by the urban people. The present study emphasizes on variations of air pollutant concentrations viz., $\mathrm{O}_{3}$, nitrogen oxides $\left(\mathrm{NO}_{\mathrm{x}}\right)$, carbon monoxide $(\mathrm{CO})$, sulfur dioxide $\left(\mathrm{SO}_{2}\right)$ and black carbon (BC) at a tropical urban site located in the Deccan plateau region with semi-arid climate. The air monitoring site revealed typical diurnal/seasonal trends attributing to the complex chemistry of surface $\mathrm{O}_{3}$ formation from its precursors. Role of $\mathrm{SO}_{2}$ in the formation of free radical $\left(\mathrm{HO}_{2}^{-}\right)$and its impact on $\mathrm{O}_{3}$ concentration is distinguished part of the study. The results showed the highest mean $\mathrm{O}_{3}$ in summer $(57.5 \pm 15.2 \mathrm{ppbv})$ followed by winter and monsoon. Observations of $\mathrm{BC}$ aerosols showed the highest mean value during winter $\left(8.2 \pm 2 \mu \mathrm{g} \mathrm{m}^{-3}\right)$ and the lowest in monsoon $\left(4.2 \pm 1 \mu \mathrm{g} \mathrm{m}^{-3}\right)$. Besides local influences, long-range transport of air masses were also studied by simulating back trajectories at different elevations during the study period. Furthermore, statistical analysis and modeling was performed with both linear (regression) and nonlinear (neural network) methods.
\end{abstract}

R. Venkanna · G. N. Nikhil · Y. V. Swamy $(\bowtie)$

Bioengineering and Environmental Sciences, Indian Institute of Chemical Technology, Hyderabad 500 007, Andhra Pradesh, India

e-mail: swamy_yv@yahoo.com

T. Siva Rao

Department of Inorganic and Analytical Chemistry, College of

Science and Technology, Andhra University, Visakhapatnam

530 003, Andhra Pradesh, India

P. R. Sinha

National Balloon Facility, Tata Institute of Fundamental

Research, Hyderabad 500 062, Andhra Pradesh, India
Keywords Air pollutants - Back trajectory $\cdot$ Modeling · Photochemistry $\cdot$ Statistics

\section{Introduction}

In the present century, urban areas deprive a healthy air quality environment due to the increase in concentration of tropospheric air pollutants such as sulfur oxides $\left(\mathrm{SO}_{\mathrm{x}}\right)$, $\mathrm{NO}_{\mathrm{x}}, \mathrm{CO}$ and $\mathrm{O}_{3}$. This decrease in air quality is a consequence of accumulation, dispersion and transformation of these air pollutants (Mazzeo et al. 2005). Increased demographic rates and rapid industrialization as well contributed for emissions with high concentrations of air pollutants (Rama Krishna et al. 2005). Air pollution caused by photochemical oxidants $\left(\mathrm{O}_{3}\right.$ and $\left.\mathrm{NO}_{\mathrm{x}}\right)$ is one of the serious problems faced by urban areas (WHO 2005). Surface $\mathrm{O}_{3}$ formed shows detrimental effect on vegetation, human health and various materials (Selvaraj et al. 2010). AbdulWahab et al. (1996) reported that anthropogenic sources are responsible for more than $95 \%$ of the $\mathrm{O}_{3}$ in the lower atmosphere.

$\mathrm{O}_{3}$ is a secondary air pollutant and is one of the green house gases in troposphere which causes global warming (Sánchez et al. 2008). $\mathrm{O}_{3}$ is not emitted directly by any natural source, but is indeed formed through a set of photochemical reactions involving primary precursors $\left[\mathrm{NO}_{\mathrm{x}}\right.$, $\mathrm{CO}$, volatile organic compounds (VOCs) etc.] under high solar radiation flux conditions (Shavrina et al. 2010). These precursor gases are emitted directly from the agricultural fields and indirectly from oxidation of fossil fuels, biomass burning and anthropogenic activities (Swamy et al. 2012a).

On the other side, destruction of $\mathrm{O}_{3}$ takes place through several pathways, mainly through surface deposition. Scavenging processes dominate the removal of $\mathrm{O}_{3}$ by $\mathrm{NO}$ 
titration and $\mathrm{SO}_{2}$ oxidation (Abdul-Wahab et al. 2005; Iliadis et al. 2007). Menon et al. (2002) and Akimoto (2003) reported $\mathrm{O}_{3}$ destruction by air-borne particulates. Black carbon is one such primary aerosol species emitted into the atmosphere through a variety of incomplete combustion of fossil fuels. Role of $\mathrm{BC}$ in $\mathrm{O}_{3}$ reduction and a major contributor to global warming was reported by Latha and Badarinath (2004).

Ground-based monitoring is important in many aspects viz., to clarify local/regional specific sources and sinks of trace gases, to derive the dynamic behavior of air pollutants and to check compliance of statistical models. These models are useful tools for air pollution and climatic studies (Arteta and Cautenet 2007). Furthermore, these models help in the development of an environmental policy, in particular to GHGs emission on a local and regional scale (Shavrina et al. 2010). But, forecasting air pollutant concentration is a difficult task due to complexity of physical and chemical processes involved. By applying multiple linear regressions (MLR), several functions can be fitted to the pollution data in terms of selected predictors. This approach is generally suitable for description of complex site-specific relations between concentrations of air pollutants and potential predictors (Abdul-Wahab et al. 2005; Swamy et al. 2013a).

Recently, artificial neural networks (ANN) model is the focus of attention, as they can handle complex and nonlinear problems better than conventional statistical techniques. Neural network is simple input-output mathematical model which extracts maximum information and reflects out the best prediction. These neural networks are noted to outperform linear regression, because it faces serious difficulties like multi-collinearity (Gardner and Dorling 1999). For regression, functional form is assumed first, such as linear or exponential, and then their coefficients minimize some measure of errors, whereas for neural networks, the method itself extracts functional form from data (McAdams et al. 2000).

In this study, environmental monitoring of surface level air pollutants inclusive of meteorological parameters was carried out at an urban site in Hyderabad, India, during the year 2010. The study observed typical temporal distribution of surface $\mathrm{O}_{3}$ and other trace gases over different time scales. An attempt was also made to understand the chemistry of $\mathrm{O}_{3}$ formation from its precursors and correlation of $\mathrm{O}_{3}$ with trace gases during different seasons. In order to know the possible transport pathways of trace gases and aerosols from their potential sources of origin, the trajectory of a hypothetical air parcel into the study site was examined. Statistical assessment between $\mathrm{O}_{3}$ and other variables was made using Pearson's correlation. Furthermore, $\mathrm{O}_{3}$ prediction was performed using two modeling strategies viz., linear regression and neural networks.

\section{Materials and methods}

The air monitoring station is located at Tata Institute of Fundamental Research-National Balloon Facility (TIFRNBF) $\left(17.47^{\circ} \mathrm{N}\right.$ and $\left.78.58^{\circ} \mathrm{E}\right)$ Hyderabad, Andhra Pradesh, India. The study site is situated on a Deccan plateau at an altitude of $536 \mathrm{~m}$ a.m.s.l. Hyderabad is the capital of Andhra Pradesh state and is fifth largest metropolitan city in India, with population of about 8 million (http://www. censusindia.gov.in). Climate of Hyderabad is a semi-arid type with hot summer from March to early June, followed by monsoon from late June to October and a pleasant winter from November to February. An average rainfall of $810 \mathrm{~mm}$ is observed every year. Air masses during monsoon months arrive from southwest directions, while in the other seasons wind flows from southeast direction. The maximum air temperature was observed in May (summer) and minimum in December (winter). Geographical view of the observatory (http://maps.google.co.in/maps) illustrates many industries in south, southeast and southwest directions. Vehicular traffic in Hyderabad is a major contributor to air pollution load during dawn and dusk time. The total vehicular pollution load in the city is about $1,500 \mathrm{~T} / \mathrm{day}$. Out of the total vehicular emissions, $\mathrm{CO}$, hydrocarbons, $\mathrm{NO}_{\mathrm{x}}$ and $\mathrm{SO}_{2}$ are 61.4, 34, 3.85 and $0.54 \%$, respectively (http://www.aptransport.org/html/pollution-control.htm).

Continuous monitoring of air samples were carried out for surface $\mathrm{O}_{3}, \mathrm{NO}_{\mathrm{x}}, \mathrm{CO}$ and $\mathrm{SO}_{2}$ during January to December in the year 2010 throughout the day with five-minute interval, and the data were retrieved using Envidas ${ }^{\circledR}$ software. The gas analyzers used were $\mathrm{O}_{3}$ (Model 49i, Thermo Scientific, USA), $\mathrm{NO}_{\mathrm{x}}$ (Model 42i, Thermo Scientific, USA), CO (Model 48i, Thermo Scientific, USA) and $\mathrm{SO}_{2}$ (Model 43i, Thermo Scientific, USA). The $\mathrm{O}_{3}$ analyzer works on the absorption principle, i.e., $\mathrm{O}_{3}$ molecule absorbs ultraviolet (UV) light at $254 \mathrm{~nm}$ wavelength. The degree to which the UV light is absorbed is directly related to the $\mathrm{O}_{3}$ concentration as described by the Beer-Lambert law. The $\mathrm{O}_{3}$ lower detection limit is $1 \mathrm{ppbv}$ with the response time of $20 \mathrm{~s}$. The $\mathrm{NO}_{\mathrm{x}}$ analyzer works on the principle of chemiluminescence, where nitric oxide reacts with $\mathrm{O}_{3}$ to produce a characteristic light, whose intensity is linearly proportional to the NO concentration. Lower detectable limit of $\mathrm{NO}_{\mathrm{x}}$ analyzer is $0.40 \mathrm{ppbv}$, with response time of $40 \mathrm{~s}$. The $\mathrm{CO}$ analyzer works on the principle of non-dispersive infrared absorption. The lower detection limit of the $\mathrm{CO}$ analyzer is $40 \mathrm{ppbv}$, and the response time is $30 \mathrm{~s}$. The $\mathrm{SO}_{2}$ analyzer operates on the principle of light absorption, where the $\mathrm{SO}_{2}$ molecules are excited by absorbing UV light at one wavelength and later decay to a lower energy state by emitting UV light at a different wavelength which is proportional to the $\mathrm{SO}_{2}$ concentration. The UV wavelengths emitted by the excited $\mathrm{SO}_{2}$ is detected by the photomultiplier tube (PMT). The lower 
detection limit of the $\mathrm{SO}_{2}$ analyzer is $2 \mathrm{ppbv}$, and the response time is $80 \mathrm{~s}$. Accuracy of the instruments is sustained by calibrating every week. All the analyzers were zero calibrated with dry air. Span calibration of $\mathrm{O}_{3}$ analyzer was carried out using multi-point internally assembled $\mathrm{O}_{3}$ generator. Span calibration for $\mathrm{NO}_{\mathrm{x}}, \mathrm{CO}$ and $\mathrm{SO}_{2}$ was done using their respective NIST traceable standard gases through multi-point calibrator cum dynamic dilutor (Model 146i, Thermo Scientific, USA). Black carbon measurements were made using Aethalometer (AE-21, Magee Scientific), and its working details can be obtained elsewhere (http://www.mageesci. com). This instrument used is a self-contained, automatic instrument which requires no calibration other than periodic checks of the air flow meter response. Apart from these air pollutant observations, meteorological parameters viz., temperature $(\mathrm{T})$, relative humidity $(\mathrm{RH})$, wind speed (WS) and wind direction (WD) were measured using automatic weather station (AWS) installed at the site (TIFR-NBF). Solar radiation was recorded using Epply model 8-48 pyranometer. The 8-48 model pyranometer produces a millivolt analog signal that is directly proportional to the irradiance being measured. The instrument is provided with a calibration constant which, when divided into the signal, results in the irradiance in watts per square meter $\left(\mathrm{Wm}^{-2}\right)$. Time-dependent studies and statistical analysis such as correlation, modeling and prediction were also carried out. The strength of $\mathrm{O}_{3}$ with other measured variables was analyzed by Pearson correlation. Modeling and prediction of $\mathrm{O}_{3}$ was performed using linear and nonlinear regression methods with observed $\mathrm{O}_{3}$ as dependent variable and all other factors as independent variables.

\section{Results and discussion}

Temporal study of trace gases

The diurnal variations of trace gases measured during different seasons are shown in Fig. 1. The profile of surface $\mathrm{O}_{3}$ showed a single-peak with double-trough pattern, which steadily increased from early hours of the day, then attained a peak value in the afternoon and thereafter declined in the evening. Daytime increase in $\mathrm{O}_{3}$ concentrations is a pronounced feature of urban polluted site, because of the photochemical oxidation of precursors such as $\mathrm{CO}$, and VOCs in presence of sufficient $\mathrm{NO}_{\mathrm{x}}$. Hyderabad being an urban location, $\mathrm{NO}_{\mathrm{x}}$ concentrations are commonly observed above the threshold level ( $\sim 10 \mathrm{pptv})$ which is conducive for $\mathrm{O}_{3}$ formation (Lal et al. 2000). However, $\mathrm{NO}_{\mathrm{x}}$ in the form of $\mathrm{NO}_{2}$ produces $\mathrm{O}_{3}$ by photolysis during sunlit hours, and $\mathrm{NO}$ in $\mathrm{NO}_{\mathrm{x}}$ reduces $\mathrm{O}_{3}$ during night time. This confirms the role of $\mathrm{NO}_{\mathrm{x}}$ in the formation and reduction of $\mathrm{O}_{3}$. Following are the conventional chemical reactions governing $\mathrm{O}_{3}$ levels in the lower troposphere.
$\mathrm{CO}+\mathrm{NO}+\mathrm{O}_{2} \rightarrow \mathrm{CO}_{2}+\mathrm{NO}_{2}$

$\mathrm{NO}_{2}+\mathrm{h} v \rightarrow \mathrm{NO}+\mathrm{O}\left({ }^{3} \mathrm{P}\right)$

$\mathrm{O}\left({ }^{3} \mathrm{P}\right)+\mathrm{O}_{2}+\mathrm{M}\left(\mathrm{O}_{2}\right.$ or $\left.\mathrm{N}_{2}\right) \rightarrow \mathrm{O}_{3}+\mathrm{M}$

$\mathrm{NO}+\mathrm{O}_{3} \rightarrow \mathrm{NO}_{2}+\mathrm{O}_{2}$

Maximum mean values of $\mathrm{O}_{3}, \mathrm{NO}_{\mathrm{x}}, \mathrm{CO}$ and $\mathrm{SO}_{2}$ in daytime (06:00-18:00) and nighttime (19:00-05:00) during different seasons are given in Table 1. Difference in pollutant mixing ratio during the daytime was found to be significantly different from nighttime. The low $\mathrm{O}_{3}$ concentrations observed during the night and early morning hours (Fig. 1) are due to the titration of $\mathrm{O}_{3}$ with $\mathrm{NO}$. Thereafter, $\mathrm{O}_{3}$ concentration increased and reached to a peak value in the afternoon. Daytime change in $\mathrm{O}_{3}$ level depends on the intensity of solar flux and boundary layer height (Lal et al. 2000). Increase in boundary layer height in the afternoon due to convective heating and consequent stratification, leads to the mixing of air in the lower altitude with the air in higher altitude rich in ozone concentration.

Besides, the other air pollutants viz., $\mathrm{NO}_{\mathrm{x}}, \mathrm{CO}, \mathrm{SO}_{2}$ (Fig. 1) as well showed a typical double-peak profile in reverse relation with $\mathrm{O}_{3}$ concentration: high values in the morning (08:00-09:00) and at night (21:00-22:00) with low values in the afternoon. These two peaks appear to be associated with rush hour traffic. The morning peak is prominent due to the fumigation effect, a widely discussed phenomenon in the context of dispersion of pollutants (Stull 1988). During evening time, the boundary layer descends due to low temperature and become shallow, thereby restricting the vertical diffusion of anthropogenic air pollutants from lower troposphere causing localization and prolonged evening peak, until the traffic flow subsided at late night, causing the concentration to decrease, accordingly (Tsai et al. 2008). Low wind speed $\left(<2 \mathrm{~ms}^{-1}\right)$ and high relative humidity $(>60 \%)$ might have also added up for weak diffusion of gases. However, during afternoon, concentrations of these pollutants reduced due to the increased boundary layer height causing vertical diffusion.

Surface $\mathrm{SO}_{2}$ also influenced $\mathrm{O}_{3}$ formation, and the chemistry involved is given in reactions (5-9). Role of $\mathrm{SO}_{2}$ in $\mathrm{O}_{3}$ formation is dependent on $\mathrm{HO}_{2}$ produced from $\mathrm{SO}_{2}$ (Swamy et al. 2013b). CO also acts as $\mathrm{OH}^{-}$scavenger and helps in the formation of $\mathrm{HO}_{2}$ leading to oxidation of $\mathrm{NO}$. Thus, $\mathrm{NO}_{2}$ formed again participates in $\mathrm{O}_{3}$ formation during day time.

$$
\begin{aligned}
& \mathrm{SO}_{2}+\mathrm{OH}+\mathrm{h} v \rightarrow \mathrm{HOSO}_{2} \\
& \mathrm{HOSO}_{2}+\mathrm{O}_{2}+\mathrm{h} v \rightarrow \mathrm{SO}_{3}+\mathrm{HO}_{2} \\
& \mathrm{HO}_{2}+\mathrm{NO} \rightarrow \mathrm{NO}_{2}+\mathrm{OH} \\
& \mathrm{OH}+\mathrm{CO} \rightarrow \mathrm{H}+\mathrm{CO}_{2} \\
& \mathrm{H}+\mathrm{O}_{2}+\mathrm{M} \rightarrow \mathrm{HO}_{2}+\mathrm{M}
\end{aligned}
$$



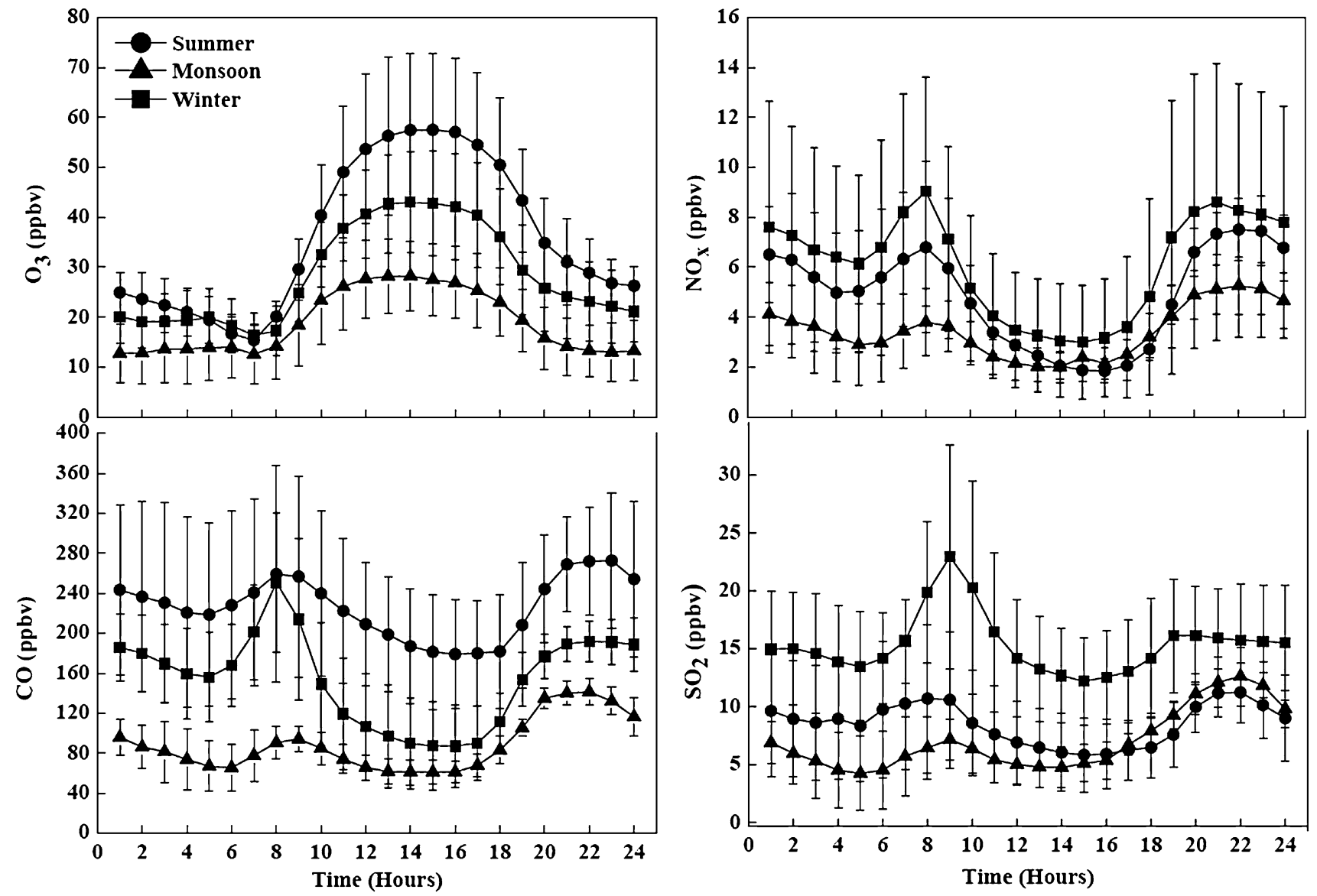

Fig. 1 Diurnal variations of $\mathrm{O}_{3}, \mathrm{NO}_{\mathrm{x}}, \mathrm{CO}$ and $\mathrm{SO}_{2}$ during different seasons

Table 1 Maximum mean along with $\mathrm{SD}$ values ' $\mathrm{A}$ ' of $\mathrm{O}_{3}, \mathrm{NO}_{\mathrm{x}}, \mathrm{CO}$ and $\mathrm{SO}_{2}$

\begin{tabular}{|c|c|c|c|c|c|c|c|c|}
\hline \multirow[t]{2}{*}{ Time (season) } & \multicolumn{2}{|l|}{$\mathrm{O}_{3}$ (ppbv) } & \multicolumn{2}{|c|}{$\mathrm{NO}_{\mathrm{x}}(\mathrm{ppbv})$} & \multicolumn{2}{|l|}{ CO (ppbv) } & \multicolumn{2}{|l|}{$\mathrm{SO}_{2}$ (ppbv) } \\
\hline & Day & Night & Day & Night & Day & Night & Day & Night \\
\hline Summer & $57.5 \pm 15.2$ & $50.5 \pm 13.4$ & $6.8 \pm 3.4$ & $7.5 \pm 1.2$ & $260.0 \pm 108.0$ & $273.0 \pm 68.0$ & $10.7 \pm 6.4$ & $11.2 \pm 2.6$ \\
\hline Monsoon & $28.2 \pm 7.0$ & $19.4 \pm 6.3$ & $3.8 \pm 1.3$ & $5.3 \pm 1.1$ & $94.0 \pm 12.6$ & $141.0 \pm 13.5$ & $7.2 \pm 1.8$ & $12.6 \pm 2.5$ \\
\hline Winter & $43.0 \pm 10.0$ & $29.5 \pm 9.0$ & $9.0 \pm 4.6$ & $8.6 \pm 5.5$ & $251.0 \pm 70.0$ & $192.0 \pm 20.0$ & $23.0 \pm 10.0$ & $16.2 \pm 4.3$ \\
\hline
\end{tabular}

Day (06:00-18:00); night (19:00-05:00)

Besides diurnal variation, all the measured trace gases showed distinct monthly and seasonal differences (Figs. 1, 2). Seasonal mean concentration of $\mathrm{O}_{3}$ was highest in summer $(57.5 \pm 15.2 \mathrm{ppbv})$, i.e., in the months of March, April and May, because of the presence of intense solar radiation and high concentrations of precursors. During monsoon seasons, i.e., July, August and September showed low $\mathrm{O}_{3}$ values $(28.2 \pm 6.7 \mathrm{ppbv})$ due to wet deposition, low sunshine and high wind speed. In winter, the precursor trace gases are entrapped in lower troposphere under humid conditions supported by low wind speed, which resulted in considerably high $\mathrm{O}_{3}$ concentrations $(43 \pm 10 \mathrm{ppbv})$ than monsoon season.
Seasonal frequency distribution of $\mathrm{O}_{3}$ during the period showed $90 \%$ of $\mathrm{O}_{3}$ lie in the range of $15-45 \mathrm{ppbv}$ and the rest in the range of 50-60 ppbv. The amplitude of $\mathrm{O}_{3}$ is highest in March, moderate in February and December and lowest in July. Sudden increase in amplitude during October is attributed to seasonal change in wind pattern from southwesterly to southeasterly. Wider amplitude observed during winter and summer months is mainly due to thermal inversion (Sánchez et al. 2008). Increase or decrease in amplitude is attributed to seasonal variations and related chemical transformations (Abdul-Wahab and Bouhamra 2004).

Besides $\mathrm{O}_{3}$ photochemistry, the other factors that influence the temporal/spatial distribution of $\mathrm{O}_{3}$ and its 


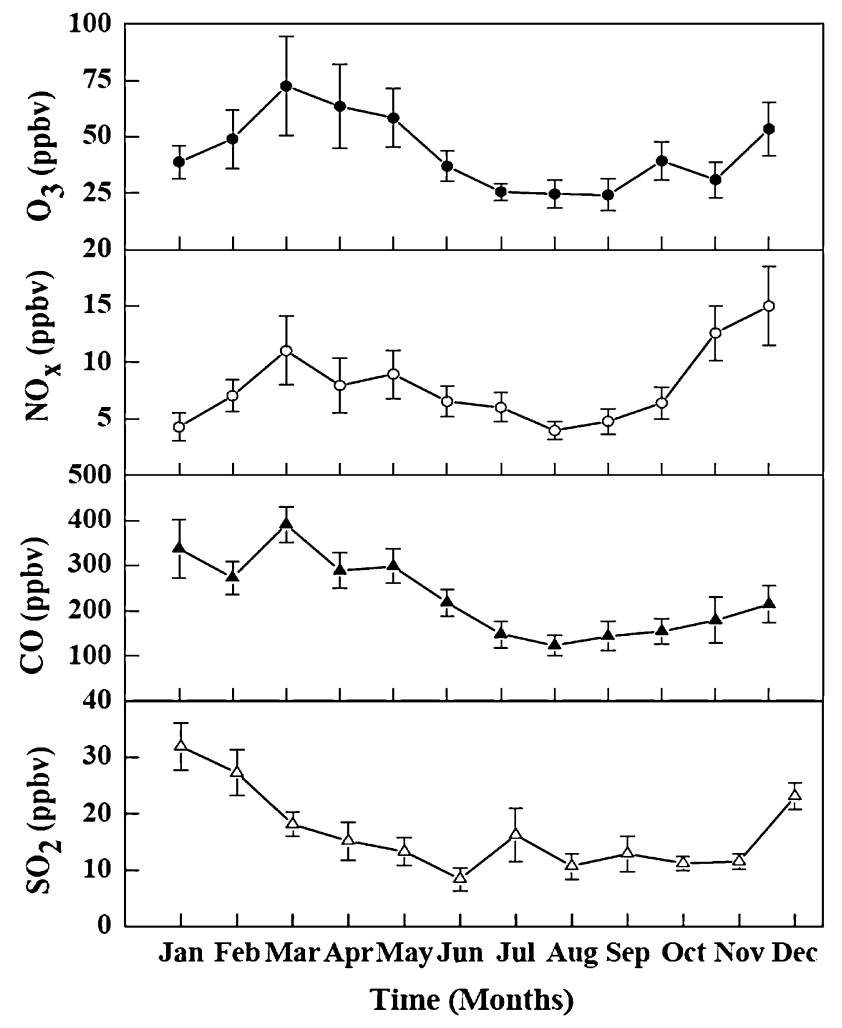

Fig. 2 Monthly variations of $\mathrm{O}_{3}, \mathrm{NO}_{\mathrm{x}}, \mathrm{CO}$ and $\mathrm{SO}_{2}$

precursors are concentration and emission rates of precursors $\left(\mathrm{NO}_{\mathrm{x}} / \mathrm{CO} / \mathrm{VOCs}\right)$ (Kleinman 1991), nature of precursor emission sources (traffic/anthropogenic/biogenic) (Swamy et al. 2012b), boundary layer dynamics, meteorological parameters and heterogeneity of the terrain (i.e., geological site topography) (Jiménez et al. 2006).

\section{Meteorological observations}

Most of the atmospheric chemical reactions occur in presence of sunlight; specifically, the shorter wavelength of light with higher energy oxidizes primary pollutants such as $\mathrm{NO}_{\mathrm{x}}$ into secondary air pollutants such as $\mathrm{O}_{3}$. The rate of reaction is dependent on the downward solar flux which is proportional to the latitude-longitude, altitude, time of the day and other radiative factors (Walcek and Yuan 1995). Further, chamber experiments also suggested that the immediate $\mathrm{NO}_{2}$ photolysis when exposed to irradiation resulted in formation of $\mathrm{O}_{3}$, and the rate of $\mathrm{O}_{3}$ formation correlates linearly with radiation flux (Lee et al. 2010). Therefore, measurement of solar radiation at the study site was important, and the observed surface $\mathrm{O}_{3}$ concentrations showed a positive correlation with solar flux (Table 2). The mean solar radiation received during the entire study (Fig. 3) showed that summer recorded a maximum value of $1,116 \pm 94 \mathrm{Wm}^{-2}$. Low solar flux was observed in monsoon $\left(842 \pm 68 \mathrm{Wm}^{-2}\right)$ followed by winter $(828 \pm 65$
Table 2 Pearson correlation matrix of $\mathrm{O}_{3}$ with different variables

\begin{tabular}{lccc}
\hline Variables & Summer & Monsoon & Winter \\
\hline $\mathrm{NO}$ & $-0.275^{* *}$ & -0.042 & $-0.221^{*}$ \\
$\mathrm{NO}_{2}$ & $-0.353^{*}$ & $-0.260^{* *}$ & $-0.461^{* *}$ \\
$\mathrm{CO}$ & $-0.241^{* *}$ & $-0.237^{* *}$ & $-0.438^{* *}$ \\
$\mathrm{SO}_{2}$ & $-0.115^{*}$ & -0.066 & $0.164^{* *}$ \\
$\mathrm{SR}$ & $0.517^{* *}$ & $0.591^{* *}$ & $0.644^{* *}$ \\
$\mathrm{~T}$ & $0.449^{* *}$ & $0.547^{* *}$ & $0.503^{* *}$ \\
$\mathrm{RH}$ & -0.082 & $-0.657^{* *}$ & $-0.618^{* *}$ \\
$\mathrm{WS}$ & 0.069 & $0.078^{*}$ & $0.508^{* *}$ \\
$\mathrm{BC}$ & $-0.240^{*}$ & $-0.254^{* *}$ & $-0.445^{* *}$ \\
\hline
\end{tabular}

* Values with $p<0.005$

** Values with $p<0.001$

$\mathrm{Wm}^{-2}$ ). Monthly variation (Fig. 4) showed a maximum mean in April and minimum mean in the month of July.

On diurnal basis (Fig. 3), $\mathrm{O}_{3}$ showed a positive correlation with temperature, which is a measure of incident solar radiation and consequently the effectiveness of photochemistry (Sillman et al. 1990; Walcek and Yuan 1995; Tu et al., 2007). Annual maximum and minimum temperatures recorded were $42{ }^{\circ} \mathrm{C}$ on May $11,2010(15: 00)$ and $13{ }^{\circ} \mathrm{C}$ on December 22 , 2010 (07:00), respectively. Summer recorded a maximum mean temperature of $35 \pm 3{ }^{\circ} \mathrm{C}$, while in monsoon and winter, the maximum mean temperatures recorded were $28 \pm 1$ and $26 \pm 4{ }^{\circ} \mathrm{C}$, respectively. Month-wise temperature profile (Fig. 4) showed high values in March, April and May and low values in November and December.

Relative humidity in the atmosphere also played a crucial role in the formation and destruction of $\mathrm{O}_{3}$ (Chen and Wang 2005), and the possible reactions are given below.

$\mathrm{O}+\mathrm{H}_{2} \mathrm{O} \rightarrow 2 \mathrm{OH}$

$\mathrm{H}^{\cdot}+\mathrm{HO}_{2} \rightarrow \mathrm{OH}^{\cdot}+\mathrm{OH}$

$\mathrm{OH}+\mathrm{O}_{3} \rightarrow \mathrm{HO}_{2}+\mathrm{O}_{2}$

$\mathrm{HO}_{2}+\mathrm{O}_{3} \rightarrow \mathrm{OH}^{-}+2 \mathrm{O}_{2}$

Along the diurnal scale, variation of $\mathrm{RH}$ depends on temperature (Fig. 3) and is anti-correlated with $\mathrm{O}_{3}$ and temperature (Table 2). Annual maximum and minimum RH were recorded as $99 \%$ on July 1, 2010 (22:00), and $17 \%$ on April 25, 2010 (16:00), respectively. Highest RH mean of $83 \pm 4 \%$ was recorded in monsoon season, while in summer and winter $\mathrm{RH}$ recorded were $60 \pm 7$ and $76 \pm 7 \%$, respectively. Monthly mean RH was highest in August and lowest in January (Fig. 4). David and Nair (2011) reported that monsoonal air hailing from the marine sources is rich in water vapor content and can cause reduction of $\mathrm{O}_{3}$ Concentration by involving $\mathrm{OH}$ radicals. These observations were supported by the air mass back trajectories simulated at the study site, which is discussed in the later part of the text. 


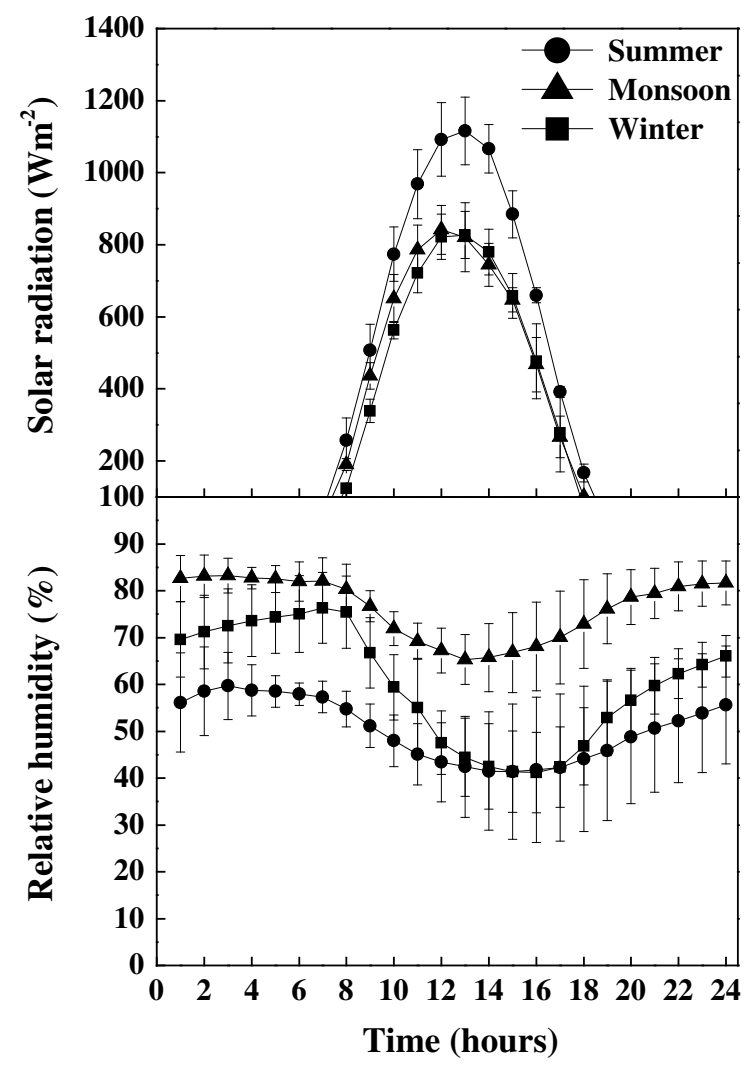

SUMMER

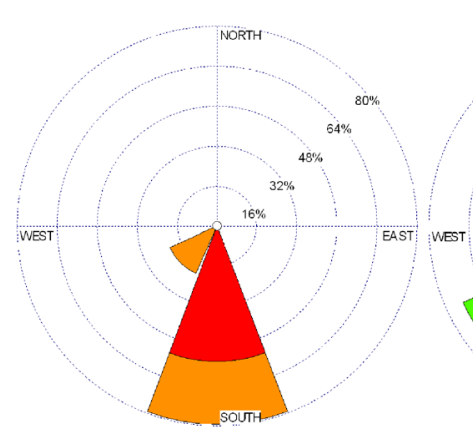

MONSOON

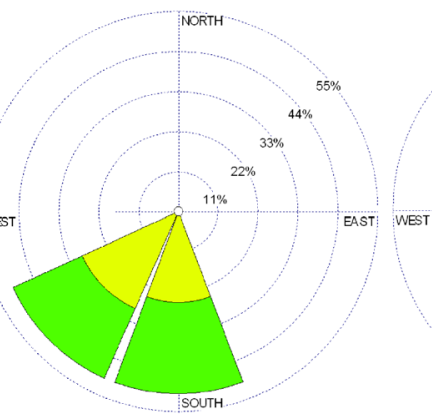

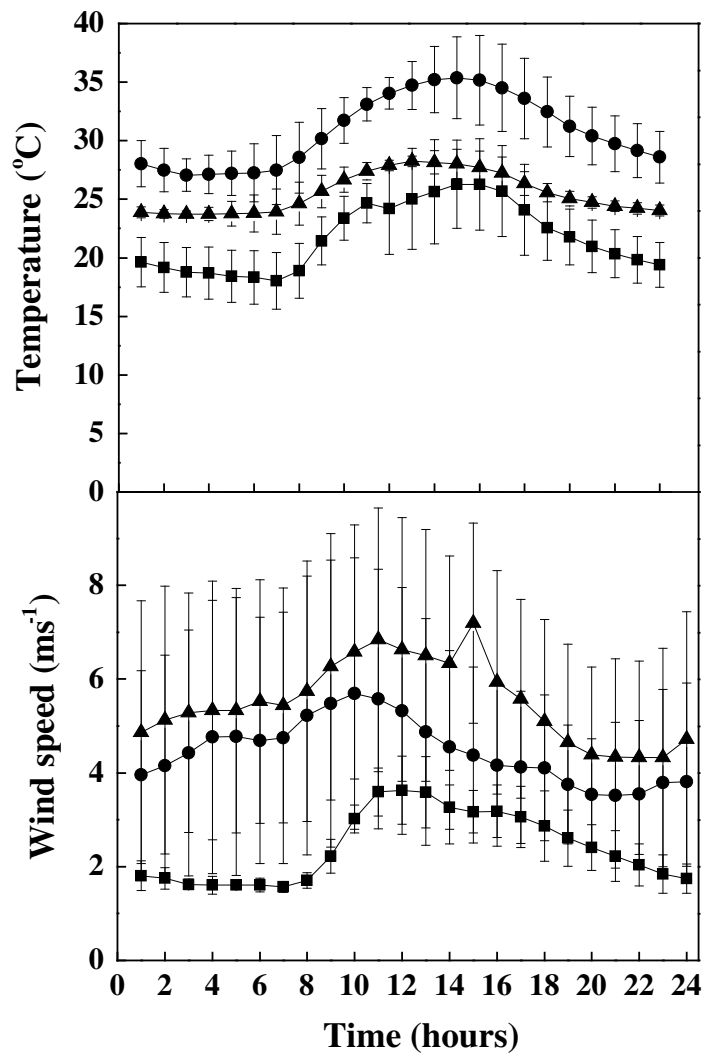

WINTER

Fig. 3 Diurnal variation of solar radiation, temperature, relative humidity and wind velocity during different seasons

Wind speed and direction also affects trace gas concentrations. It characterizes mechanical turbulence causing dilution/concentration and transport of air pollutants, while wind direction determines the path of the pollutant dispersion (Duenas et al. 2002; Rodriguez and Guerra 2001). Seasonal and monthly variation of wind speed and direction are illustrated in Figs. 3 and 4, respectively. Summer showed calm winds from south direction. Monsoon showed strong winds from southwest direction. In winter, moderate winds prevailed from southeast direction.

Monthly profile of wind speed and direction showed notable changes during February-March, June-July and October-November due to seasonal transitions. A fair estimate of dispersion of air pollutants in the atmosphere is possible based on the frequency distribution of wind velocity (Manju et al. 2002). Observations made in summer showed $56 \%$ of calm winds (WS $<2.4 \mathrm{~ms}^{-1}$ ) and $44 \%$ of soft winds $\left(2.4 \leq \mathrm{WS} \leq 4.0 \mathrm{~ms}^{-1}\right)$ from the south direction. These calm winds can influence $\mathrm{O}_{3}$ concentration at the site. Monsoon showed $75 \%$ of strong winds $\left(5.6 \leq \mathrm{WS} \leq 8.5 \mathrm{~ms}^{-1}\right)$ and $25 \%$ of moderate winds $\left(4.1 \leq \mathrm{WS} \leq 5.5 \mathrm{~ms}^{-1}\right)$ from southwest direction. Low $\mathrm{O}_{3}$ concentrations was observed in monsoon due to the strong winds that dilute air by carrying $\mathrm{O}_{3}$ precursors away from the site. In winter, a combination of calm $(60 \%)$, soft (30\%) and moderate winds $(10 \%)$ arrived from southeast direction. 


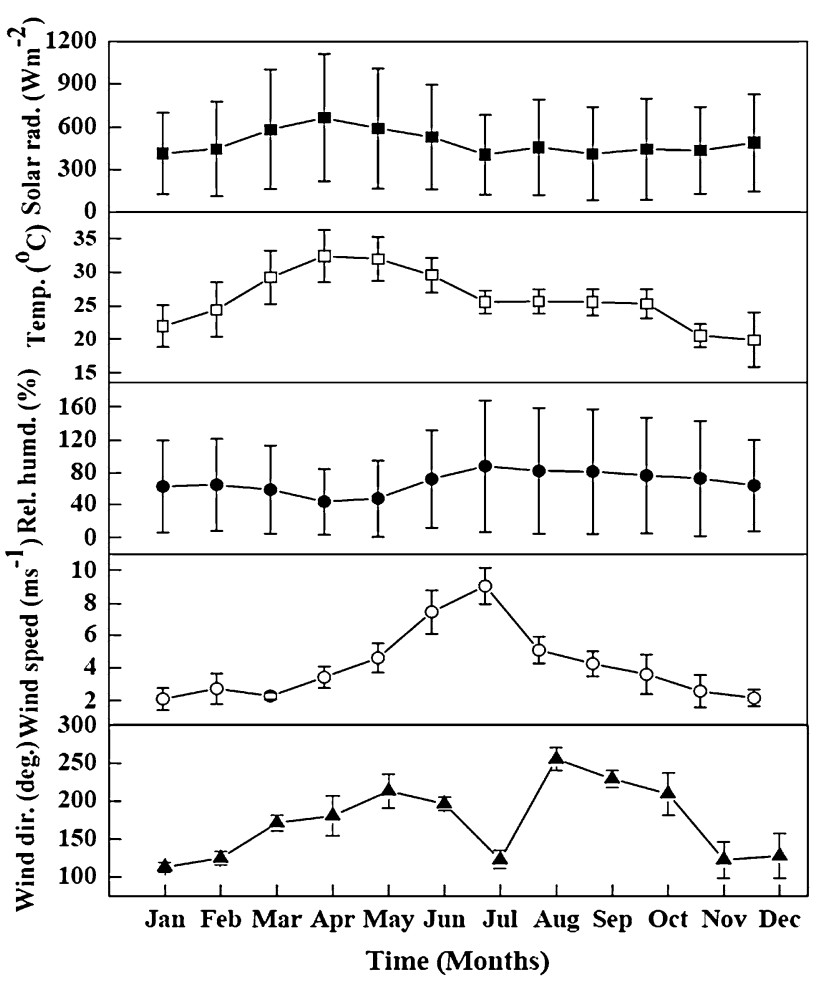

Fig. 4 Monthly variation of meteorological parameters

Therefore, the net $\mathrm{O}_{3}$ formed is comparatively higher in winter than in monsoon, but lower than summer.

\section{Black carbon}

Diurnal pattern of BC mass concentration during different seasons (Fig. 5a) showed two peaks; first sharp peak in the morning (07:00-09:00) and second broad peak at night (19:00-21:00). These peaks are mainly attributed to vehicular traffic emissions. Gradual increase in BC concentrations after evening hours (17:00) was observed from domestic activities (Pathak et al. 2010) and surface-based inversion (Ganguly et al. 2006). The decrease in BC concentration in midnight hours is due reduction in traffic density and sedimentation (02:00-05:00 h). Also, fumigation effect in the boundary layer brings down $\mathrm{BC}$ aerosols from the nocturnal residual layer until sunrise and thereafter increases again with traffic (Tripathi et al. 2005).

Annual mean $\mathrm{BC}$ mass concentrations ranged between 2 and $10 \mu \mathrm{g} \mathrm{m}^{-3}$ during the entire study period. Highest mean $\mathrm{BC}$ concentration was observed in winter $\left(8.2 \pm 2 \mu \mathrm{g} \mathrm{m}^{-3}\right)$, followed by summer $\left(5.3 \pm 3 \mu \mathrm{g} \mathrm{m}^{-3}\right)$, and lowest in monsoon $\left(4.2 \pm 1 \mu \mathrm{g} \mathrm{m}^{-3}\right)$. High mean BC values in winter were due to entrapment of pollutant emissions in the shallow boundary layer. In addition, meteorological parameters such as low temperature and calm winds localize the pollutant concentration (Pathak et al. 2010). In monsoon, low values were recorded due to scavenging effect of rainfall (Kumar
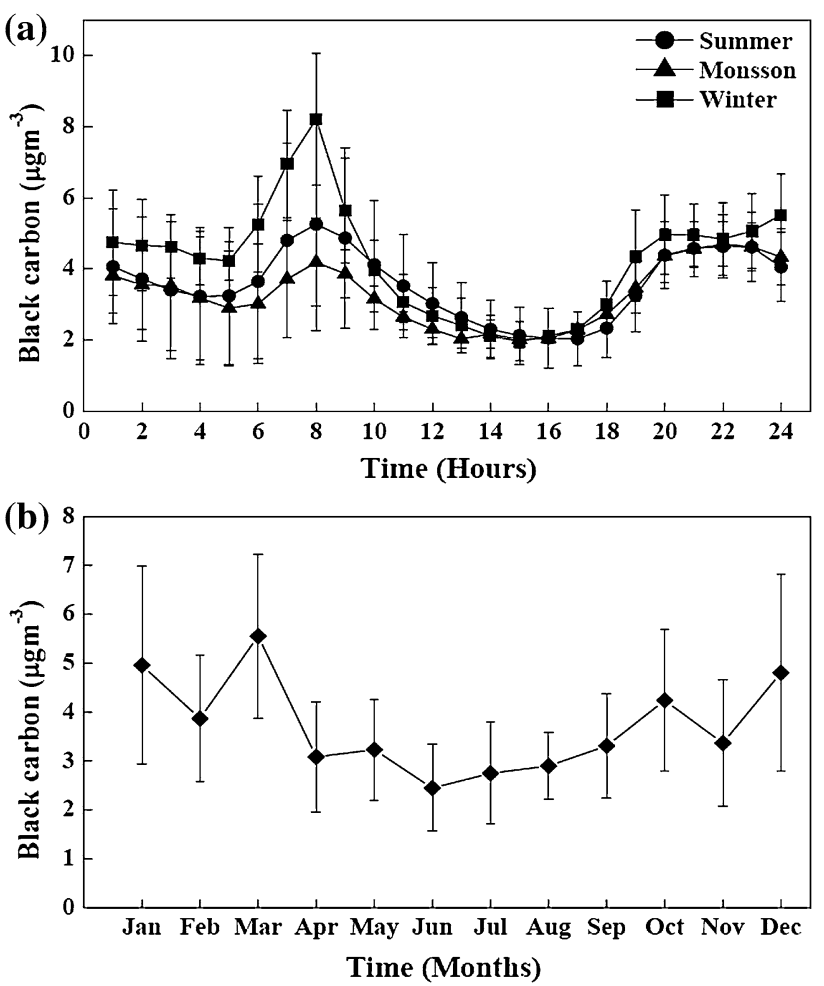

Fig. 5 a Diurnal variation of black carbon during different seasons, b monthly variation of black carbon

et al. 2011) and also due to mechanical turbulence of wind shear (Babu et al. 2002).

Monthly mean BC distribution profile (Fig. 5b) showed high values in January, March, October and December due to biomass burning and air mass transport. Minimum BC values were observed during June, July and August because of wet surface deposition by rain. It was observed that during the morning and evening peak traffic hours (Fig. 5a) high BC mass concentration showed significant $\mathrm{O}_{3}$ reduction attributing to $\mathrm{BC}-\mathrm{O}_{3}$ heterogeneous chemistry (Latha and Badarinath 2004; Fendel et al. 1995), besides NO titration.

Transport of air pollutants

Air mass back trajectories are calculated at different elevations: 300,800 and $1,500 \mathrm{~m}$ a.g.l such that the trajectory terminated at TIFR-NBF, Hyderabad at 12:30 IST to commensurate with the $\mathrm{O}_{3}$ observations using the Air Resources Laboratory's Hybrid Single-Particle Lagrangian Integrated Trajectory (HYSPLIT) model (v.4.8) (http:// www.arl.noaa.gov/ready/hysplit4.html).

Back trajectories were simulated in conjunction with seasonal change to understand the air mass transport and source of origin (Fig. 6). In summer, transport of trace gases occurred at heights $<1,000 \mathrm{~m}$ a.g.l indicating its origin from local and also from regional surroundings 
located in western and southwestern directions. Trajectories in the last week of summer (end of June) indicated onset of monsoon from Arabian Sea. Trajectories above $1,500 \mathrm{~m}$ a.g.l indicated $\mathrm{BC}$ aerosol transport from intercontinental areas. In monsoon, clean and fresh air originated from Arabian Sea (south-west direction), which implied marine transport. In winter, the air mass approached to the site was mainly of continental type. Venkataraman et al. 2005 reported that air parcel from western, eastern and central India contains trace gases and BC particles in high concentrations. Hence, these attributions made could be considered, which have impacted the change in air pollutant concentrations.

Statistical modeling

Surface $\mathrm{O}_{3}$ being a secondary pollutant (dependent/response variable), its concentration is influenced by two major factors (independent variables or predictors) namely air pollutant concentrations ( $\mathrm{NO}, \mathrm{NO}_{2}, \mathrm{CO}, \mathrm{SO}_{2}$ and $\mathrm{BC}$ ) and meteorological conditions (SR, T, RH, WS). Assuming the predictors are often linearly correlated with response variable, a stepwise linear regression was employed. In this method, the variables are added iteratively to the model, until no additional variables contributed significantly to explain the variance of response variable. Before regression, the predictors were checked for variable inflation factor (VIF), which estimated multi-colinearity between dependent and independent variables. Only selective variables were considered for regression analysis. Among the total available data records, 1,050, 1,668 and 1,320 were used for summer, monsoon and winter, respectively. The regression process resulted in model equations $(14,15$ and 16) and its statistics inferred that variables showed $>50 \%$ of overall variance in the observed $\mathrm{O}_{3}$ for all three seasons (Fig. 7a).

Summer : $\mathrm{O}_{3}$

$$
\begin{aligned}
= & 28.9-(3.66 *[\mathrm{NO}])-(0.0251 *[\mathrm{CO}]) \\
& +(0.0186 * \mathrm{SR})+(1.14 * \mathrm{~T})
\end{aligned}
$$

Monsoon : $\mathrm{O}_{3}=122-\left(0.013 *\left[\mathrm{NO}_{2}\right]\right)+(0.0290 *[\mathrm{CO}])$

$$
\begin{aligned}
& +(0.0118 * \mathrm{SR})-(1.93 * \mathrm{~T})-(0.746 * \mathrm{RH}) \\
& -(1.43 * \mathrm{BC})
\end{aligned}
$$

Winter : $\mathrm{O}_{3}$

$$
\begin{aligned}
= & 41.6-\left(0.620 *\left[\mathrm{NO}_{2}\right]\right)-(0.0165 *[\mathrm{CO}]) \\
& +\left(0.403 *\left[\mathrm{SO}_{2}\right]\right)+(0.0107 * \mathrm{SR}) \\
& +(0.440 * \mathrm{~T})-(0.276 * \mathrm{RH}) \\
& +(1.69 * \mathrm{WS})-(0.462 * \mathrm{BC})
\end{aligned}
$$

However, multi-collinearity is always a serious problem with large data points with numerous variables. Although the predictors were checked for VIF value to minimize the multicollinearity problem, a deeper look in the results still revealed the persistence of the same problem. This could be
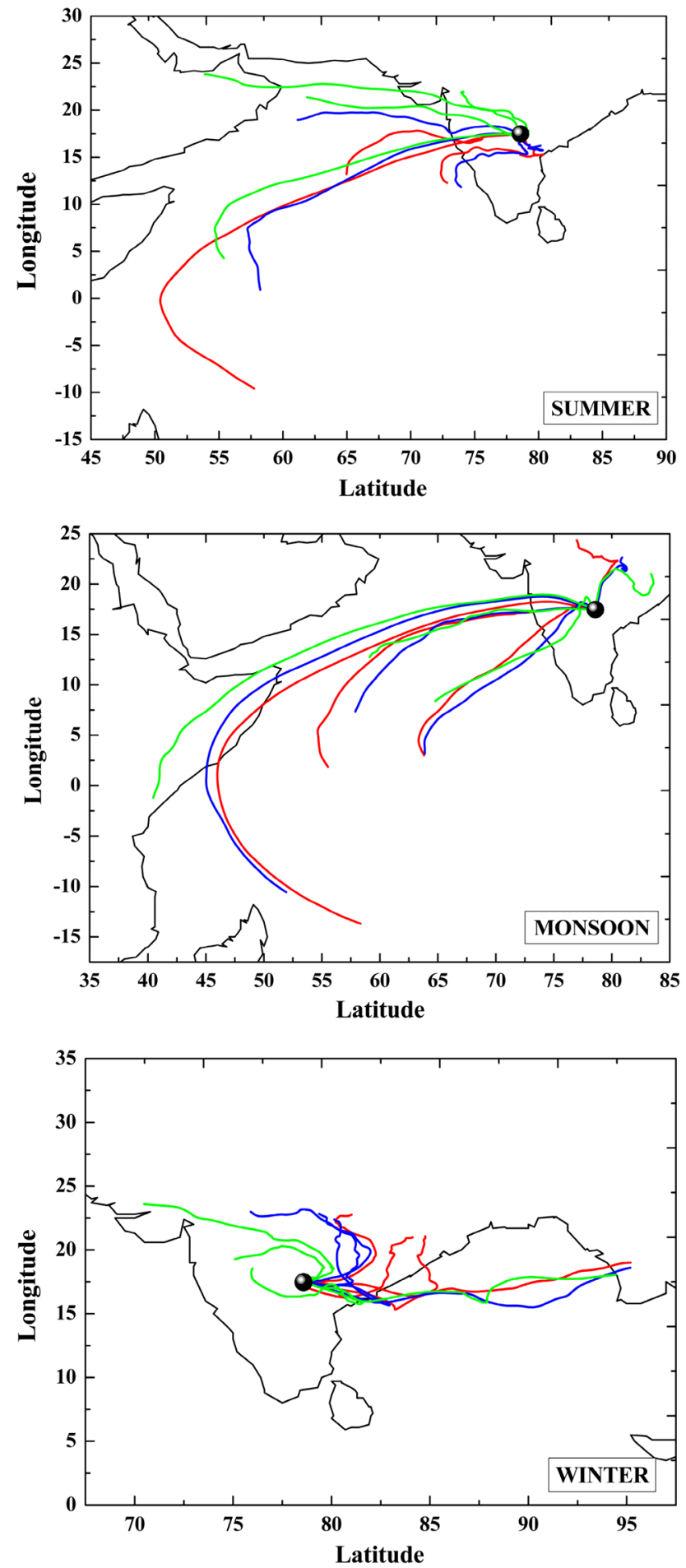

$300 \mathrm{~m}$ (red), $800 \mathrm{~m}$ (blue) and $1500 \mathrm{~m}$ (green) above ground level

Fig. 6 Air mass back trajectories during different seasons and different heights

minimized if all possible conditions and factors influencing the response variable are considered in a nonlinear model.

An optimal nonlinear model using ANN was constructed with automatic architecture by employing 

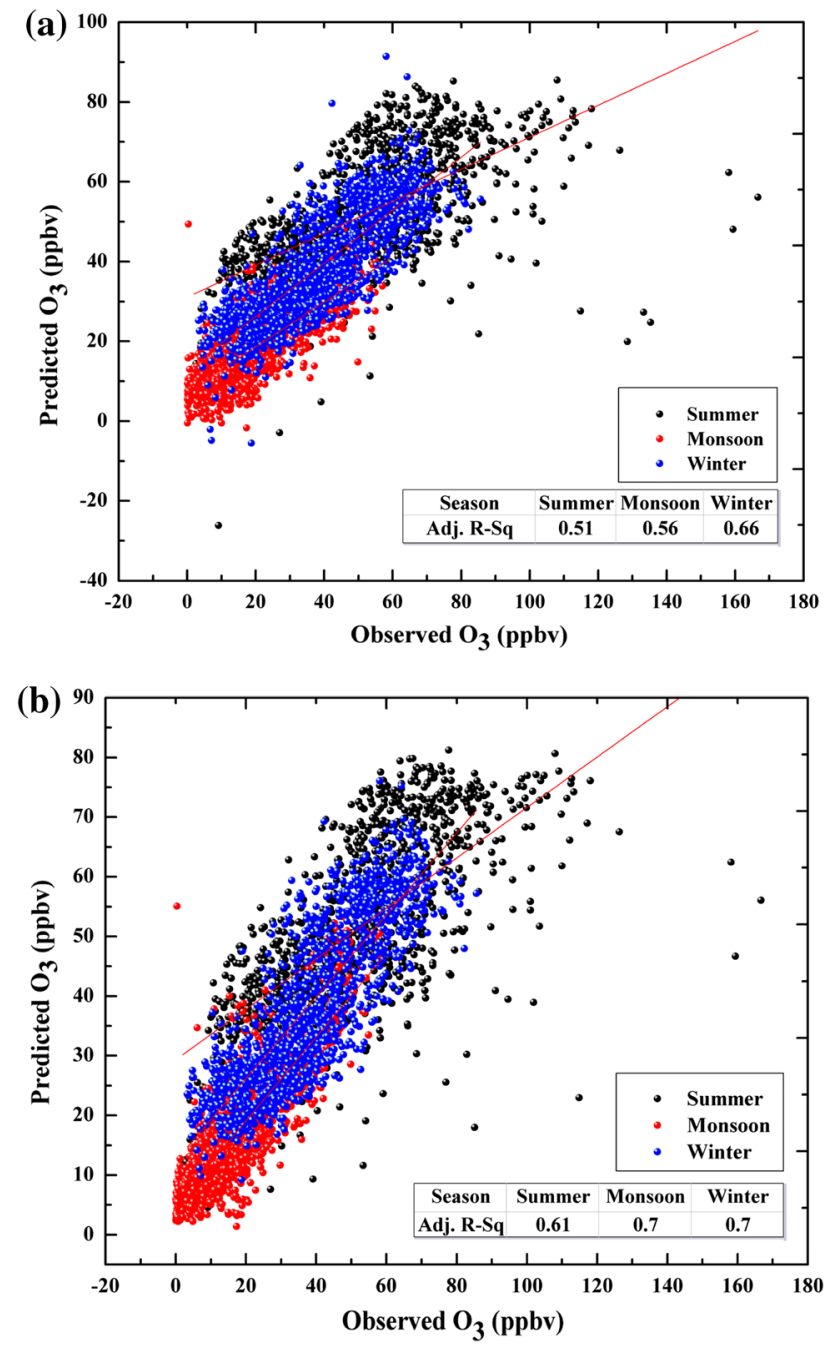

Fig. 7 Scatter plots of $\mathrm{O}_{3}$-predicted versus observed using a multiple linear regression and $\mathbf{b}$ multi-layer perceptron

multilayer perceptron (MLP) method, which is commonly cited by many authors and elsewhere (Inal 2010; Kolehmainen et al. 2001). Out of the 4,038 totally available data records, $70 \%$ of data records were used in training process and only $30 \%$ were used for testing process. The model was evaluated with hyperbolic tangent (TanH) transfer function, in batch mode. Sensitivity analysis was carried out to correlate the maximum change in output with changes in the $n$th predictor. The ANN model used resulted in overall variance of $>60 \%$ (Fig. 7b), revealing the influence of $\mathrm{NO}_{\mathrm{x}}, \mathrm{CO}$, solar radiation, temperature, relative humidity and black carbon on $\mathrm{O}_{3}$ concentration.

In both the models, discrepancies between observed and predicted values were due to other factors that are not considered in this study (such as VOCs, dust, particulate matter, etc.). However, ANN model showed higher variance than linear regression. It is clear that the use of ANN model offers greater reliability and high degree of accuracy on the issue of local $\mathrm{O}_{3}$ modeling using different predictors, since $\mathrm{O}_{3}$ formation is a nonlinear process involving complex reactions.

\section{Conclusion}

The study reported temporal variations of $\mathrm{O}_{3}$ and its precursors (viz., $\mathrm{NO}_{\mathrm{x}}, \mathrm{CO}$ and $\mathrm{SO}_{2}$ ) during different months/ seasons for the year 2010. It was observed that $\mathrm{O}_{3}$ concentration varied with change in concentrations of precursors and local meteorology. Complex atmospheric chemistry of these trace gases has played a significant role in the formation of peroxide free radicals which were involved in $\mathrm{O}_{3}$ formation. Back trajectories have shown transport of air masses from long distances with different sources of origin during various seasons which have affected air pollutant concentrations at our site. Furthermore, the model equations derived from statistical analysis using MLR and ANN revealed significant variables such as $\mathrm{NO}_{\mathrm{x}}, \mathrm{CO}, \mathrm{SR}, \mathrm{T}, \mathrm{RH}$ and $\mathrm{BC}$ which influenced $\mathrm{O}_{3}$ concentration. The predicted values obtained showed higher regression coefficients supporting nonlinear formation of $\mathrm{O}_{3}$. The credible part of this work is to understand the role of $\mathrm{O}_{3}$ precursor gases on the formation of $\mathrm{O}_{3}$ with statistical analysis and modeling (linear and nonlinear approaches) at a semi-arid tropical urban site.

Acknowledgments The authors wish to thank the Director, Indian Institute of Chemical Technology, for encouragement and support. Fruitful discussions and constant support extended by Prof. Shyam Lal and Dr. C.B.S Dutt and Dr. P.P.N Rao Programme Director during the course of this project is highly acknowledged. We also acknowledge AT/CTM under ISRO-GBP trace gas programme for financial support and Tata Institute of Fundamental Research (National Balloon Facility) at Hyderabad for providing laboratory space. The authors would like to extend their gratitude to the NOAA-ARL (HYSPLIT), for providing the data for trajectory simulations.

Conflict of interest The authors have declared no conflict of interest.

\section{References}

Abdul-Wahab SA, Bouhamra WS (2004) Diurnal variations of air pollution from motor vehicles in Khaldiya residential area Kuwait. J Environ Stud 61(1):73-98

Abdul-Wahab SA, Bouhamra WS, Ettouney H, Sowerby B, Crittenden BD (1996) A statistical model for predicting ozone levels in the Shuaiba industrial area in Kuwait. Environ Sci Pollut Res 3(4): 195-200

Abdul-Wahab SA, Bakheitb CS, Al-Alawia SM (2005) Principal component and multiple regression analysis in modelling of ground-level ozone and factors affecting its concentrations. Environ Model Softw 20(10):1263-1271

Akimoto H (2003) Global air quality and pollution. Science 302(5651):1716-1719

Arteta J, Cautenet S (2007) Study of ozone distribution over the south-eastern France (ESCOMPTE campaign): discrimination 
between ozone tendencies due to chemistry and to transport. J Atmos Chem 58(2):111-130

Babu SS, Satheesh SK, Moorthy KK (2002) Aerosol radiative forcing due to enhanced black carbon at an urban site in India. Geophys Res Lett 29:1880-1884

Chen J, Wang P (2005) Effect of relative humidity on electron distribution and ozone production by DC coronas in air. IEEE Trans Plasma Sci 33(2):808-812

David LM, Nair PR (2011) Diurnal and seasonal variability of surface ozone and $\mathrm{NO}_{\mathrm{x}}$ at a tropical coastal site: association with mesoscale and synoptic meteorological conditions. J Geophys Res 116:D10303-D10318

Duenas C, Fenandez MC, Canete S, Carretero J, Liger E (2002) Assessment of ozone variations and meteorological effects in an urban area in the Mediterranean coast. Sci Tot Environ 299(1-3):97-113

Fendel W, Matter D, Burtscher H, Schmidt-Ott A (1995) Interaction between carbon or iron aerosol particles and ozone. Atmos Environ 29(9):967-973

Ganguly D, Jayaraman A, Gadhavi H (2006) Physical and optical properties of aerosols over an urban location in western India: seasonal variabilities. J Geophys Res 111:D24206-D24227

Gardner MW, Dorling SR (1999) Neural network modelling and prediction of hourly $\mathrm{NO}_{\mathrm{x}}$ and $\mathrm{NO}_{2}$ concentrations in urban air in London. Atmos Environ 33(5):709-719

Iliadis LS, Spartalis SI, Paschalidou AK, Kassomenos P (2007) Artificial neural network modelling of the surface ozone concentration. Int J Comp Appl Math 2(2):125-138

Inal F (2010) Artificial neural network prediction of tropospheric ozone concentrations in Istanbul, Turkey. Clean: Soil, Air, Water 38(10):897-908

Jiménez P, Jorba O, Parra R, Baldasano JM (2006) Evaluation of MM5-EMICAT2000-CMAQ performance and sensitivity in complex terrain: high-resolution application to the northeastern Iberian Peninsula. Atmos Environ 40(26):5056-5072

Kleinman LI (1991) Seasonal dependence of boundary layer peroxide concentration: the low and high $\mathrm{NO}_{\mathrm{x}}$ regimes. J Geophys Res 96(D11):20721-20733

Kolehmainen M, Martikainen H, Runskanen J (2001) Neural networks and periodic components used in air quality forecasting. Atmos Environ 35(5):815-825

Kumar RK, Narasimhulu K, Balakrishnaiah G, Reddy BSK, Rama Gopal K, Reddy RR, Satheesh SK, Moorthy KK, Babu SS (2011) Characterization of aerosol black carbon over a tropical semiarid region of Anantapur, India. Atmos Res 100(1):12-27

Lal S, Naja M, Subbaraya BH (2000) Seasonal variation in the surface ozone and its precursors over an urban site in India. Atmos Environ 34(17):2713-2724

Latha KM, Badarinath KVS (2004) Correlation between black carbon aerosols, carbon monoxide, and tropospheric ozone over a tropical urban site. Atmos Res 71(4):265-274

Lee SB, Bae GN, Lee YM, Moon KC, Mansoo Choi M (2010) Correlation between Light Intensity and Ozone Formation for Photochemical Smog in Urban Air of Seoul. Aerosol Air Qual Res 10(6):540-549

Manju N, Balakrishnan R, Mani N (2002) Assimilative capacity and pollutant dispersion studies for the industrial zone of Manali. Atmos Environ 36(21):3461-3471

Mazzeo NA, Laura EV, Choren HL (2005) Analysis of NO, $\mathrm{NO}_{2}, \mathrm{O}_{3}$ and $\mathrm{NO}_{\mathrm{x}}$ concentrations measure data green area of Buenos Aires City during wintertime. Atmos Environ 39(17):3055-3068

McAdams HT, Crawford RW, Hadder GR (2000) A vector approach to regression analysis and its application to heavy-duty diesel emissions. Society of Automotive Engineers, Inc, Contract with the Energy Division of Oak Ridge National Laboratory (ORNL), Contract No. DE-AC05-00OR22725
Menon S, Hansen J, Nazarenko L, Luo Y (2002) Climate effects of black carbon aerosols in China and India. Science 297(5590):2250-2253

Pathak B, Kalita G, Bhuyan K, Bhuyan PK, Moorthy KK (2010) Aerosol temporal characteristics and its impact on shortwave radiative forcing at a location in the northeast of India. J Geophy Res 115:D19204-D19218

Rama Krishna TVBPS, Reddy MK, Reddy RC, Singh RN (2005) Impact of an industrial complex on the ambient air quality: case study using a dispersion model. Atmos Environ 39(29):5395-5407

Rodriguez S, Guerra JC (2001) Monitoring of ozone in a marine environment in Tenerife (Canary Islands). Atmos Environ 35(10):1829-1841

Sánchez ML, García MA, Pérez IA, de Torre B (2008) Evaluation of surface ozone measurements during 2000-2005 at a rural area in the upper Spanish plateau. J Atmos Chem 60(2):137-152

Selvaraj RS, Elampari K, Gayathri R, Johnson Jeyakumar S (2010) A neural network model for short term prediction of surface ozone at tropical city. Int J Eng Sci Tech 2(10):5306-5312

Shavrina AV, Pavlenko YV, Veles AA, Sheminova VA, Synyavski II, Sosonkin MG, Romanyuk YO, Eremenko NA, Ivanov YS, Monsar OA, Kroon M (2010) Tropospheric ozone columns and ozone profiles for Kiev in 2007. Astro-Physical EP

Sillman S, Logan J, Wofsy S (1990) The sensitivity of ozone to nitrogen oxides and hydrocarbons in regional ozone episodes. J Geophys Res 95(D2):1837-1851

Stull RB (1988) An introduction to boundary layer meteorology. Kluwer Academic, Boston

Swamy YV, Nikhil GN, Venkanna R, Das SN, Roy Chaudhury G (2012a) Emission of methane and nitrous oxide from Vigna mungo and Vigna radiata legumes in India during the dry cropping seasons. Atmósfera 25(1):107-120

Swamy YV, Venkanna R, Nikhil GN, Chitanya DNSK, Sinha PR, Ramakrishna M, Rao AG (2012b) Impact of nitrogen oxides, volatile organic compounds and black carbon on atmospheric ozone levels at a semi arid urban site in Hyderabad. Aerosol Air Qual Res 12:662-671

Swamy YV, Nikhil GN, Venkanna R, Chitanya DNSK, Sinha PR, Shailaja S, Rao AG (2013a) Role of nitrogen oxides, black carbon, and meteorological parameters on the variation of surface ozone levels at a tropical urban site-Hyderabad, India. Clean-Soil Air Water 41(3):215-225

Swamy YV, Sharma AR, Nikhil GN, Venkanna R, Chitanya DNSK, Sinha PR (2013b) The impact assessment of Diwali fireworks emissions on the air quality of a tropical urban site, Hyderabad, India, during three consecutive years. Environ Monit Assess 185:7309-7325

Tripathi SN, Dey S, Tare V, Satheesh SK (2005) Aerosol black carbon radiative forcing at an industrial city in northern India. Geophys Res Lett 32:L08802-L08806

Tsai DH, Wang JL, Wang CH, Chan CC (2008) A study of groundlevel ozone pollution, ozone precursors and subtropical meteorological conditions in central Taiwan. J Environ Monit 10:109-118

Tu J, Xia ZG, Wang H, Li W (2007) Temporal variations in surface ozone and its precursors and meteorological effects at an urban site in China. Atmos Res 85:310-337

Venkataraman C, Habib G, Figuren-Fernandez A, Miguel AH, Friedlander SK (2005) Residential bio-fuels in South Asia: carbonaceous aerosol emissions and climate impacts. Science 307(5714):1454-1456

Walcek CJ, Yuan H-H (1995) Calculated influence of temperaturerelated factors on ozone formation rates in the lower troposphere. J Appl Meteorol 34(5):1056-1069

WHO (2005) Air quality guidelines for particulate matter, ozone, nitrogen dioxide and sulfur dioxide. World Health Organization, Global update 2005:1-22 